\title{
Influence of electrolytic plasma nitriding mode on structural phase state of pearlitic steel
}

\author{
Natalya Popova ${ }^{1,2, *}$, Lyudmila Erygina $^{3}$,Elena Nikonenko $^{1,4}$, and Mazhin Skakov ${ }^{3}$ \\ ${ }^{1}$ Tomsk State University of Architecture and Building, 634003 Tomsk, Russia \\ ${ }^{2}$ Institute of Strength Physics and Material Science, Siberian Branch, Russian Academy of Sciences, \\ 634021 Tomsk, Russia \\ ${ }^{3}$ National Nuclear Center of the Republic of Kazakhstan, 071100 Kurchatov, Kazakhstan \\ ${ }^{4}$ National Research Tomsk Polytechnic University, 634050 Tomsk, Russia
}

\begin{abstract}
The paper describes results of studies of phase transitions in structural phase state occurring in the type $0.34 \mathrm{C}-1 \mathrm{Cr}-1 \mathrm{Ni}-1 \mathrm{Mo}-\mathrm{Fe}$ steel under electrolytic plasma nitriding in nitrogen-containing water solution. The nitriding voltages considered in the given study were 550 and $600 \mathrm{~V}$. The research was conducted by means of X-ray diffraction electron microscopy. The specimens were studied in two states: 1) before modification (original state) and 2) after nitriding in the surface layer of the specimen. The study was conducted on thin foils. It was found that nitriding lead to significant changes in the structure of steel, namely in its phase composition and in the number of existing phases. In the original state the structure of steel was given as lamellar pearlite, ferritic carbide mix and fragmented ferrite. After $550 \mathrm{~V}$ nitriding it was lath martensite, plates of $\alpha$-phase, with colonies of thin parallel plates of $\gamma$-phase and coarse grains of $\alpha$-phase, containing $\gamma$-phase grains which were different in size and shape and were various-directional. Increase in nitriding voltage up to $600 \mathrm{~V}$ lead to change in the structure given as a lamellar nonfragmented pearlite and fragmented ferrite. The original state was marked by presence of particles of $\mathrm{M}_{3} \mathrm{C}$ cementite, after nitriding irrespective of the voltage it had the particles of $\mathrm{M}_{3} \mathrm{C}$ alloyed cementite, $\mathrm{Fe}_{3} \mathrm{Mo}_{3} \mathrm{~N}$ nitride and $\mathrm{Cr}_{2} \mathrm{C}_{0.61} \mathrm{~N}_{0.39}$ carbonitride. The sizes, volume fractions and locations of particles were dependent on nitriding voltage.
\end{abstract}

\section{Introduction}

Advancement of technology and development of new branches of industry require application of new high-strength and resistant materials. Special attention is being paid to different ways of surface treatment as the properties of the ready products are to a large extend dependent on the properties of the product surface. Thus it stipulated rapid development of scientific studies as well as engineering solutions aimed at enhancing the traditional and development of new surface treatment techniques in order to provide surface with the required operational properties [1]. Modern methods of materials modification are

*Corresponding author: natalya-popova-44@mail.ru 
based on intensification of the applied impact, use of electric discharge in particular. Electrolyte plasma treatment refers to one of the mentioned methods [2-7]. It implies that during the components heating along with quenching the surface layers of metals undergo chemical modification with elements contained in the electrolyte composition. By means of changing the electrolyte composition and electric mode, it is possible to conduct surface treatment under larger velocities, which sufficiently exceeds the velocity of thermal gas phase and electrolytic processes. High heating and cooling rates enable to improve a number of mechanical properties (e.g. hardness and strength), and simplify mechanization and automatization of industrial processes of hardening. In these conditions processing period is considerably declined [8]. And also low-cost compact equipment can be used [8]. Moreover, high heating rates enable to combine both the advantages of ion-beam and highfrequency processing [9-16].

The present work is aimed at studying the influence of electric mode of electrolytic plasma nitriding on the patterns of changing the structure and phase composition of the type 0.34C-1Cr-1Ni-1Mo-Fe pearlitic steel.

\section{Materials and methods}

The object of the given study was the type $0.34 \mathrm{C}-1 \mathrm{Cr}-1 \mathrm{Ni}-1 \mathrm{Mo}-\mathrm{Fe}$ steel; its chemical composition is given in Table 1.

Table 1. Chemical composition of the type $0.34 \mathrm{C}-1 \mathrm{Cr}-1 \mathrm{Ni}-1 \mathrm{Mo}-\mathrm{Fe}$ steel (wt.\%).

\begin{tabular}{|c|c|c|c|c|c|c|c|c|c|}
\hline \multicolumn{10}{|c|}{ Mass content of elements, \% } \\
\hline $\mathbf{C}$ & $\mathbf{S i}$ & $\mathbf{M n}$ & $\mathbf{N i}$ & $\mathbf{C r}$ & $\mathbf{M o}$ & $\mathbf{S}$ & $\mathbf{P}$ & $\mathbf{C u}$ & $\mathbf{F e}$ \\
\hline $0.3-$ & $0.17-$ & $0.5-$ & $1.3-$ & $1.3-$ & $0.2-$ & not & not & not & \\
0.4 & 0.37 & 0.8 & 1.7 & 1.7 & 0.3 & more & more & more & the rest \\
& & & 0.035 & 0.03 & 0.3 & \\
\hline
\end{tabular}

The study of steel was conducted on thin foils by means of X-ray diffraction (XRD) electron microscopy using EM-125 transmission electron microscope (TEM) at $125 \mathrm{kV}$ accelerating voltage. Operating increase in the microscope column was chosen equal to 8000 up to 50000 volumes. Changes in structural phase composition occuring in $0.34 \mathrm{C}$ $1 \mathrm{Cr}-1 \mathrm{Ni}-1 \mathrm{Mo}-\mathrm{Fe}$ steel under electrolytic plasma nitriding in nitrogen-containing water solution were studied at two nitriding modes: $550 \mathrm{~V}(5 \mathrm{~min})$ and $600 \mathrm{v}(5 \mathrm{~min})$. The specimen were examined in two states: 1) before modification (original state) and 2) after nitriding in the surface layer of the specimen.

Foils production technique for TEM observations for each of the exact locations was prior described in [17].

The phase analysis and identification were held according to standard methodologies using the TEM images confirmed by the micro-diffraction images and dark-field images obtained in the respective reflexes. It allowed performing classification of the structure morphology, defining the sizes and volume fractions of secondary phases as well as places of their localization, and parameters of material fine structure. 


\section{Results and discussion}

\subsection{Structure and phase composition of steel in the original state}

Structural phase composition of the type $0.34 \mathrm{C}-1 \mathrm{Cr}-1 \mathrm{Ni}-1 \mathrm{Mo}-\mathrm{Fe}$ steel was previously described in details in [18]. It was established that the structure of steel in the original state was first, lamellar pearlite, with its volume fraction comprising $35 \%$ of the volume of material matrix. Lamellar pearlite was present in two modifications: non-fragmented pearlite (Fig. 1a) and fragmented pearlite (Fig. 1b). Volume fraction of non-fragmented pearlite was $10 \%$, of fragmented one $-25 \%$. The second structural component of steel was ferritic-carbide mix (Fig. 1c), its volume fraction in the material matrix was $45 \%$. The third structural component of steel was fragmented ferrite (Fig. 1d), its volume fraction was $20 \%$.

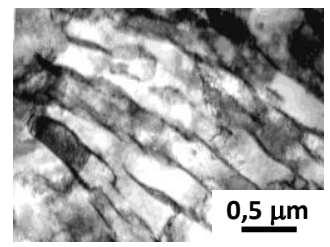

(a)

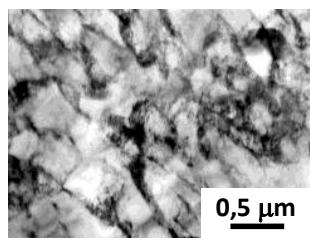

(b)

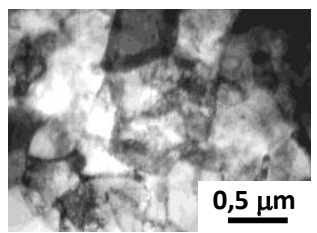

(c)

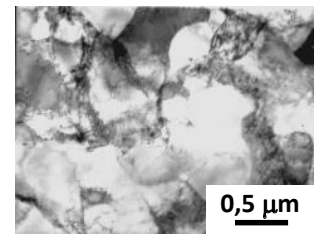

(d)

Fig. 1. Electron microscope image of the type $0.34 \mathrm{C}-1 \mathrm{Cr}-1 \mathrm{Ni}-1 \mathrm{Mo}-\mathrm{Fe}$ steel fine structure in the original state: lamellar pearlite (a), fragmented lamellar pearlite (b), ferritic-carbide mix (c), fragmented ferrite $(d)$.

Carbide component in steel was only present by the particles of $(\mathrm{Fe}, \mathrm{Cr})_{3} \mathrm{C}$ or $\mathrm{M}_{3} \mathrm{C}$ alloyed cementite, with volume fraction of $5.1 \%$.

\subsection{Structure and phase composition of steel nitride at $\mathrm{U}=550 \mathrm{~V}$}

Steel nitriding $550 \mathrm{~V}(5 \mathrm{~min})$ lead to a significant change of phase composition, the number of existing phases and their morphology. Thus, both phase composition and fine steel structure in the near-surface layer of nitrided specimen varied considerably from the original state. The obtained structure could be classified into three types: 1) lath martensite; 2) relatively large-size grains (plates) of $\alpha$-phase, with colonies of thin parallel $\gamma$-phase plates inside; 3 ) mixture of $\alpha$ - and $\gamma$-phases grains.

Lath martensite occupied the main fraction of the material $(\sim 60 \%)$. The typical example is given in Figure 2a. Indexing of microdiffraction images obtained from the area of lath martensite showed that retained austenite ( $\gamma$-phase) was detected along the boundaries of martensite laths. Retained austenite had the form of elongated interlayers. Dark-field image obtained in coinciding reflexes [200] $\alpha+[421] \gamma$ can be seen in Figure 2d. This phase had face-centered cubic (fcc) crystal lattice. It was established that crystal lattices of $\alpha$-phase and $\gamma$-phase were bounded by Kurdyumov-Sachs orientation relationship [19]. The average size of $\gamma$-phase interlayers comprised the value of $20 \times 250 \mu \mathrm{m}$. Volume fraction of $\gamma$-phase in lath martensite was $4.5 \%$. 


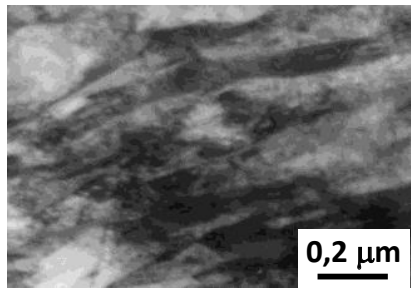

(a)

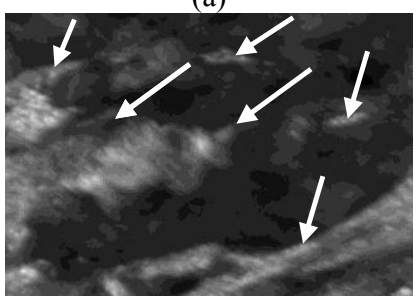

(d)

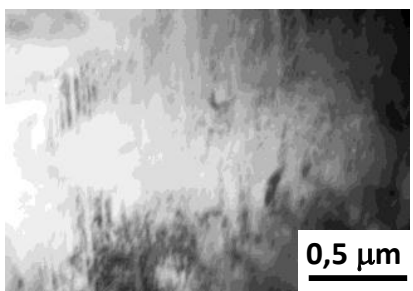

(b)

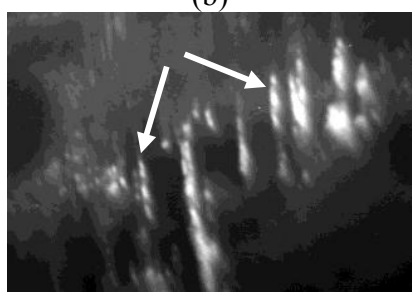

(e)

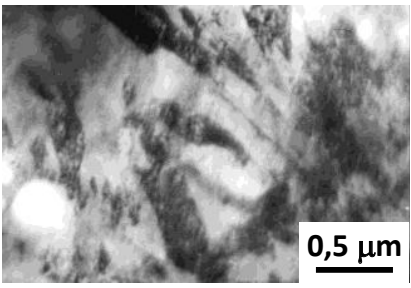

(c)

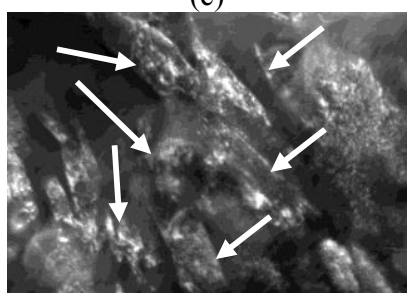

(f)

Fig. 2. Electron microscope image of fine structure of the type $0.34 \mathrm{C}-1 \mathrm{Cr}-1 \mathrm{Ni}-1 \mathrm{Mo}-\mathrm{Fe}$ steel after nitriding at $\mathrm{U}=550 \mathrm{~V}, 5 \mathrm{~min}$ : a, $\mathrm{d}$ - lath martensite, $\mathrm{b}, \mathrm{e}-$ grain of $\alpha$-phase with colony of thin parallel plates of $\gamma$-phase, $c, f-$ mix of grains of $\alpha$ - and $\gamma$-phases (a-c - bright-field images, $d$-fdark-field images). White arrows on dark-field images denote $\gamma$-phase precipitation.

Grains (or short wide plates) of $\alpha$-phase, with colonies of thin parallel plates (like twins) of $\gamma$-phase inside were the second component of the steel matrix structure after nitriding at $\mathrm{U}=550 \mathrm{~V}$. Volume fraction of this structure comprised $10 \%$ of the total material volume. The typical example of such structure is given in Figure $2 \mathrm{~b}$ where we can see the image of grain with a group of twin-type thin plates inside. Indexing of microdiffraction image obtained from the area of this group of plates showed that these plates were lamellar precipitate of $\gamma$-phase. Dark-field image (Fig. 2e) obtained in the reflex [111] of $\gamma$-phase serves as a confirmation for that. Crystal lattices of $\alpha$ - and $\gamma$-phases, like in lath martensite were bounded by Kurdyumov-Sachs orientation relationship. Volume fraction of $\gamma$-phase in this structure was $30 \%$.

The third component of the steel matrix structure after nitriding at $\mathrm{U}=550 \mathrm{~V}$ was a mix of grains of $\alpha$ - and $\gamma$-phases. This mix consisted of large-size grains of $\alpha$-phases containing elements of $\gamma$-phase which were different in size and shape and were various directional, given in the shape of plates varying in width and length, globes or fine grains. The fraction of this structure was $30 \%$ in the total material volume. The typical example of this structure is given in Figure 2c; Figure 2f shows dark-field image obtained in the reflex [ 220] of $\gamma$ phase. Between the crystal lattices of $\alpha$ - and $\gamma$-phases Kurdyumov-Sachs orientation relationship was also followed. The volume fraction of $\gamma$-phase in this structure was $40 \%$.

Indexing of microdiffraction images showed that in all constituent elements of the steel matrix structure except for reflexes belonging to $\alpha$ - and $\gamma$-phases, there were reflexes of one more phase $-\mathrm{Fe}_{3} \mathrm{Mo}_{3} \mathrm{~N}$ nitride, and in lath martensite there was also $\mathrm{Cr}_{2} \mathrm{C}_{0,61} \mathrm{~N}_{0,39}$ carbonitride and $\mathrm{M}_{3} \mathrm{C}$ alloyed cementite.

$\mathrm{Fe}_{3} \mathrm{Mo}_{3} \mathrm{~N}$ nitride had a complex face-centered cubic (fcc) crystal lattice. The particles of $\mathrm{Fe}_{3} \mathrm{Mo}_{3} \mathrm{~N}$ nitride were inside the interlayers or grains of $\gamma$-phase. This was especially well seen on dark-field images, obtained in reflexes referring to crystal lattice of $\mathrm{Fe}_{3} \mathrm{Mo}_{3} \mathrm{~N}$ phase. Corresponding examples of dark-field images obtained in reflexes [ T1 T ] of $\gamma$-phase $+[240]$ of $\mathrm{Fe}_{3} \mathrm{Mo}_{3} \mathrm{~N}$ phase and [220] of $\gamma$-phase $+[711]$ of $\mathrm{Fe}_{3} \mathrm{Mo}_{3} \mathrm{~N}$ phase are given in 
Figure 3 a,b. Irrespective of the location of $\mathrm{Fe}_{3} \mathrm{Mo}_{3} \mathrm{~N}$ nitride its particles were of a round shape. Their size was $10-15 \mu \mathrm{m}$. Their volume fraction in $\gamma$-phase was $\sim 2 \%$.

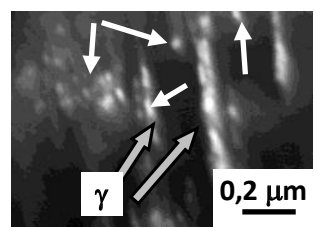

(a)

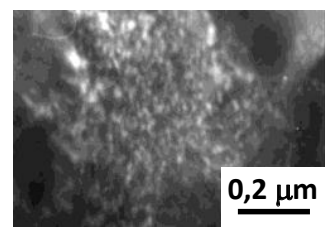

(b)

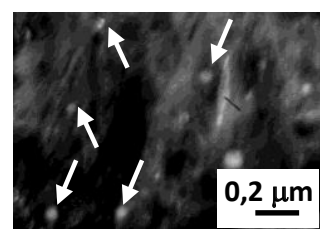

(c)

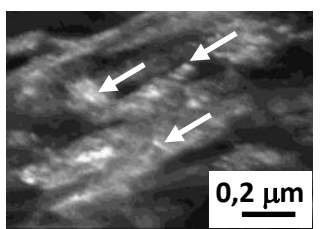

(d)

Fig. 3. Particles of $\mathrm{Fe}_{3} \mathrm{Mo}_{3} \mathrm{~N}$ nitride inside the interlayers (a) and grains (b) of $\gamma$-phase, in $\alpha$-phase of $\mathrm{Cr}_{2} \mathrm{C}_{0,61} \mathrm{~N}_{0,39}$ carbonitride (c) and $\mathrm{M}_{3} \mathrm{C}$ alloyed cementite (d). Dark-field images. Type $0.34 \mathrm{C}-1 \mathrm{Cr}-$ $1 \mathrm{Ni}-1 \mathrm{Mo}-\mathrm{Fe}$ steel after nitriding at $\mathrm{U}=550 \mathrm{~V}, 5 \mathrm{~min}$.

$\mathrm{Cr}_{2} \mathrm{C}_{0,61} \mathrm{~N}_{0,39}$ carbonitride had orthorhombic crystal lattice. The particles of $\mathrm{Cr}_{2} \mathrm{C}_{0,61} \mathrm{~N}_{0,39}$ carbonitride could be found only in lath martensite, as has been mentioned before. They had a round shape and were randomly located in lath martensite. Dark-field image obtained in the reflex [212] of $\mathrm{Cr}_{2} \mathrm{C}_{0,61} \mathrm{~N}_{0,39}$ phase is given in Figure 3c. The average particles size comprised $50 \mu \mathrm{m}$, their volume fraction in lath martensite was $\sim 1 \%$.

The particles of $\mathrm{M}_{3} \mathrm{C}$ alloyed cementite were present only in lath martensite. They were located inside the laths. Dark-field image obtained in reflexes [200] of $\alpha$-phase + [341] of $\mathrm{M}_{3} \mathrm{C}$ phase is given in Figure $3 \mathrm{~d}$. The average particles size was $30 \times 50 \mu \mathrm{m}$, the volume fraction of cementite inside the laths comprised $\sim 2 \%$.

\subsection{Structure and phase composition of steel nitride at $U=600 \mathrm{~V}$}

Increase in the voltage of steel nitriding up to $\mathrm{U}=600 \mathrm{~V}$ leads to changes in the steel structure, varying considerably both from the original structure and from the steel nitrided at $\mathrm{U}=550 \mathrm{~V}$. In this case, morphology of fine structure was given as lamillar nonfragmented pearlite in the amount of $45 \%$ and fragmented ferrite in the amount of $55 \%$. Typical electron microscope images of fine structure obtained from different parts of the material are given in Figure 4.

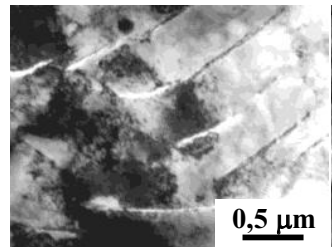

a)

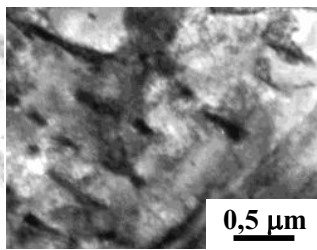

b)

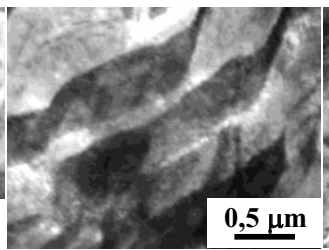

(c)

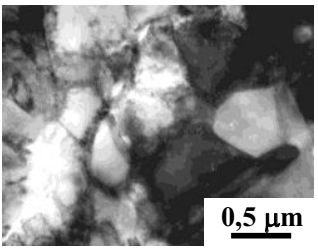

(d)

Fig. 4. Electron microscope images of fine structure of the type $0.34 \mathrm{C}-1 \mathrm{Cr}-1 \mathrm{Ni}-1 \mathrm{Mo}-\mathrm{Fe}$ steel after nitriding at $\mathrm{U}=600 \mathrm{~V}, 5 \mathrm{~min}$ : $\mathrm{a}-\mathrm{c}$ - lamellar pearlite $(\mathrm{a}$ - ideal, b - with destructed plates of cementite, $\mathrm{c}$ - defective); $\mathrm{d}$ - fragmented ferrite.

As can be seen from Figures 4a-c, lamellar pearlite was present in three states: 1) nearly ideal lamellar pearlite (Fig. 4a); 2) lamellar pearlite with destructed cementite plates (Fig. 4b); and 3) defective lamellar pearlite (Fig. 4c). Fragmented ferrite (Fig. 4d) like in the original steel state was given as isotropic fragments. 
XRD analysis showed that microdiffraction images in all states of lamellar pearlite except for reflexes of $\alpha$-phase and $\mathrm{M}_{3} \mathrm{C}$ alloyed cementite had reflexes referring to $\mathrm{Fe}_{3} \mathrm{Mo}_{3} \mathrm{~N}$ phase. Moreover, in the first and second states of lamellar pearlite the particles of $\mathrm{Fe}_{3} \mathrm{Mo}_{3} \mathrm{~N}$ phase were present in $\alpha$-phase on dislocations, forming 'spotted' contrast and in the third state inside the plates of $\mathrm{M}_{3} \mathrm{C}$. This is well seen on dark-field images obtained in reflexes [ 110] of $\alpha$-phase $+[022] \mathrm{M}_{3} \mathrm{C}+[006]$ of $\mathrm{Fe}_{3} \mathrm{Mo}_{3} \mathrm{~N}$ phase (Fig.5a), [200] $\alpha$ phase $+\left[\right.$ T30] $\mathrm{M}_{3} \mathrm{C}+\left[\right.$ [135] of $\mathrm{Fe}_{3} \mathrm{Mo}_{3} \mathrm{~N}$ phase (Fig. 5b) and [440] of $\mathrm{Fe}_{3} \mathrm{Mo}_{3} \mathrm{~N}$ phase (Fig. 5c). The particles possessed round shape. The average size of particles being in dislocations in $\alpha$-phase was $12 \mu \mathrm{m}$, inside the cementite plates $-25 \mu \mathrm{m}$. Their volume fraction in $\alpha$-phase in the first and second states of lamellar pearlite were almost the same and comprised $\sim 1 \%$, in cementite plates (third state of lamellar pearlite) it was $3 \%$.

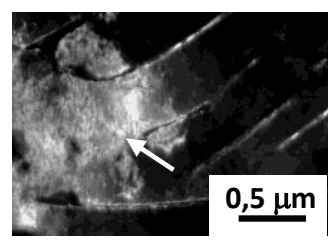

(a)

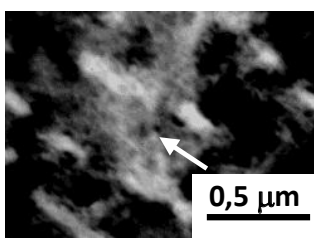

(b)

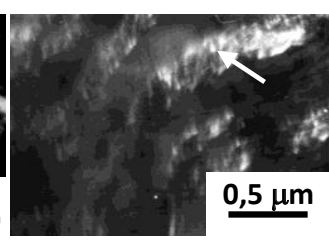

(c)

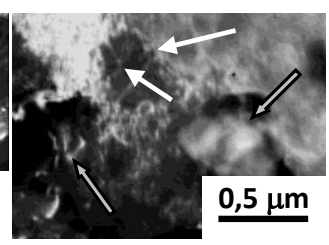

(d)

Fig. 5. Electron microscope image of fine structure of the type $0.34 \mathrm{C}-1 \mathrm{Cr}-1 \mathrm{Ni}-1 \mathrm{Mo}-\mathrm{Fe}$ steel after nitriding at $\mathrm{U}=600 \mathrm{~V}, 5 \mathrm{~min}$ : $\mathrm{a}-\mathrm{c}$ - lamellar pearlite $(\mathrm{a}$ - ideal, $\mathrm{b}$ - with destructed cementite plates, $\mathrm{c}$ - defective); $\mathrm{d}$ - fragmented ferrite. Precipitation of particles of $\mathrm{Fe}_{3} \mathrm{Mo}_{3} \mathrm{~N}$ nitride (marked by white arrows) in $\alpha$-phase of lamellar pearlite ( $\mathrm{a}$ - ideal and $\mathrm{b}$ - with destructed cementite plates), in cementite plates in defected lamellar pearlite (c) and inside on the boundaries of fragments in ferrite (d) and $\mathrm{Cr}_{2} \mathrm{C}_{0,61} \mathrm{~N}_{0,39}$ carbonitride particle (marked by grey arrows) on the boundaries and in the joints of fragments in ferrite (d). Dark-field images. Type 0.34C-1Cr-1Ni-1Mo-Fe steel after nitriding at $\mathrm{U}$ $=600 \mathrm{~V}, 5 \mathrm{~min}$.

The particles of $\mathrm{Fe}_{3} \mathrm{Mo}_{3} \mathrm{~N}$ nitride were also present in fragmented ferrite. They were also of a round shape and were located inside the fragments on dislocations and on the boundaries of fragments (Fig. 5d). The average size of particles both inside and on the boundaries of fragments was the same and comprised $20 \mu \mathrm{m}$; the volume fraction in fragmented ferrite was $3 \%$.

The particles of $\mathrm{Cr}_{2} \mathrm{C}_{0.61} \mathrm{~N}_{0.39}$ carbonitride (Fig. 5d) were located on the boundaries and in the joints of fragments, they had irregular shape, and comparatively large size $(150 \mu \mathrm{m})$ in regards to particles of $\mathrm{Fe}_{3} \mathrm{Mo}_{3} \mathrm{~N}$ phase. Volume fraction in fragmented ferrite was $2 \%$.

\section{Conclusion}

From the outcome of the present study it can be concluded that nitriding leads to:

1) Change of the morphological components of the steel matrix;

2) New precipitation of secondary phases: $\mathrm{Cr}_{2} \mathrm{C}_{0.61} \mathrm{~N}_{0.39}$ carbonitride and $\mathrm{Fe}_{3} \mathrm{Mo}_{3} \mathrm{~N}$ nitride.

It was established that the increase of the nitriding voltage significantly changes the morphology of steel phase structure.

The present study was conducted with the financial support of Russian Foundation for Basic Research within the research project No. 16-48-700198. 


\section{References}

1. I.V. Suminov, P.N. Belkin, et al., Mir materialov $i$ tehnologij [The world of materials and technologies] 1 (Tehnosfera, Moscow, 2011) (in Russian)

2. M.K. Skakov, L.B. Bayatanova, M. Scheffler, Tribologia 5, 147-153 (2012)

3. J. Martin, A. Melhem, I. Shchedrina, T. Duchanoy, A. Nominé, G. Henrion, T. Czerwiec, T. Belmonte, Surface \& Coatings Technology 221, 70 (2013)

4. V.V. Bedin, L.Kh. Baldaev, D.V. Kolmykov, M.B. Kovynev, Vestnik of Kursk State Agricultural Academy 1, 77-80 (2013) (in Russian)

5. E. Kozlov, N. Popova, L. Zhurerova, E. Nikonenko, M. Kalashnikov, M. Skakov, AIP Conf. Proc. 1783, 020112 (2016)

6. K. Rokosz, T. Hryniewicz, World Scientific News 35, 441 (2016)

7. N. Popova, L. Bayatanova, E. Nikonenko, M. Skakov, Ed. Kozlov, AIP Conf. Proc. 1800, 030002 (2017)

8. P.N. Belkin, Elektrohimiko-termicheskaja obrabotka metallov $i$ splavov [Electrochemical and thermal treatment of metals and alloys] (Mir, Moscow, 2005) (in Russian)

9. R.R. Grin, R.F. Gallyamova, N.Yu. Dudareva, A.A. Sirenko, F.F. Musin, Letters on Materials 3(15), 1 (2014) (in Russian)

10. S.K. Kiseleva, L.I. Zainullina, M.M. Abramova, A.A. Pinegina, N.Y. Dudareva, I.V. Alexandrov, J. Eng. Sci. Technol. Review 8, Special Issue 6, 6 (2015)

11. F.F. Komarov, Ionnaja implantacija $v$ metally [Ion implantation in metals] (Metallurgija, Moscow, 1990) (in Russian)

12. I.A. Kurzina, E.V. Kozlov, N.A. Popova, M.P. Kalashnikov, E.L. Nikonenko, K.P. Savkin, E.M. Oks, Yu.P. Sharkeev, Bull. Russ. Academy Sci. Physics 76(11), $1238(2012)$

13. M. Kovaleva, M. Prozorova, M. Arseenko, M. Yapryntsev, Y. Tyurin, O. Kolisnichenko, N. Vasilik, V. Sirota, I. Pavlenko, Ceramics International 41(10), 15061 (2015)

14. A.G. Grigoryants, I.N. Shiganov, A.I. Misyurov, V.S. Mikhailov, N.P. Kolomeyets, Welding International 29, 6, 475 (2015)

15. P.N. Belkin, S.Yu. Shadrin, Int. J. Heat and Mass Transfer 55, 1-3, 179 (2012)

16. S.A. Kusmanov, A.A. Smirnov, Yu.V. Kusmanova, P.N. Belkin, Surface and Coatings Technology 269, 308 (2015)

17. N.A. Popova, L.G. Zhurerova, E.L. Nikonenko, M.K. Skakov, Vestnik of Tomsk State University. Chemistry 1, 60 (2016) (in Russian)

18. N.A. Popova, L.A. Erygina, E.L. Nikonenko, M.K. Skakov, N.A. Koneva, E.V. Kozlov, Bull. Russ. Academy Sci. Physics 81(3), 354 (2017)

19. G.V. Kurdyumov, L.M. Utevskiy, R.I. Entin, Prevrashhenija $v$ zheleze $i$ stali [Transformations in iron and steel] (Nauka, Moscow, 1977) (in Russian) 